

\title{
Müze Deneyimini Etkileyen Unsurlar: Çevrimiçi Yorumlar Üzerine Nitel Bir Araştırma
}

Dr. Öğr. Üyesi Serhat Adem SOP, Burdur Mehmet Akif Ersoy Üniversitesi, Turizm İşletmeciliği ve Otelcilik Yüksekokulu, Burdur, e-posta: serhatademsop@gmail.com

ORCID: https://orcid.org/0000-0001-9096-9496

Dr. Öğr. Üyesi, Utku ONGUN, Burdur Mehmet Akif Ersoy Üniversitesi, Turizm İşletmeciliği ve Otelcilik Yüksekokulu, Burdur, e-posta: utkuongun@mehmetakif.edu.tr

ORCID: https://orcid.org/0000-0002-0722-6382

Rıdvan ABALI, Yüksek Lisans Öğrencisi, Burdur Mehmet Akif Ersoy Üniversitesi, Sosyal Bilimler Enstitüsü, Burdur, e-posta: ridvan.abali@outlook.com

ORCID: https://orcid.org/0000-0001-9408-971X

Öz

Bireylerin müze deneyimini olumlu ve olumsuz etkileyen unsurları belirlemek üzere yürütülen bu çalışmada nitel araştırma yaklaşımı uygulanmıştır. Bu kapsamda, 11.12.2012 - 11.11.2019 tarihleri arasında TripAdvisor platformunda Burdur Müzesi ile ilgili yapılmış olan tüm çevrimiçi yorumlar incelenmiş ve müze deneyimine ilişkin değerlendirmelerin yer aldığ yorum içerik analizine tabi tutulmuştur. Elde edilen nitel veri MAXQDA yazılımından yararlanılarak çözümlenmiştir. Araştırmanın sonucunda, Burdur Müzesi'nin “antik kent çağrışımı, eser ve heykellerin niteliği, ilgili personel, ulaşım kolaylığı, iç tasarım, açıklayıcı ve işaretler, çevredeki mekânlar, engelli bireylere uygunluk, temizlik ve bakım, çağdaş müzecilik anlayışı" olmak üzere toplam 10 alt kategoride olumlu deneyimi destekleyici nitelik taşıdığ belirlenmiştir. Ziyaretçilerin müze deneyimini olumsuz etkileyen unsurlar ise "alanın küçük olması, bilgilendirme materyallerinin yetersizliği, aydınlatma sorunları, satış mağazasının bulunmaması" olmak üzere dört alt kategoriyle açıklanmıştır. Araştırmanın sonuçlarına paralel olarak müze yöneticileri ve gelecek araştırmalar için değerlendirmelerde bulunulmuştur.

Anahtar Kelimeler: Müze Deneyimi, Çevrimiçi Ziyaretçi Yorumları, TripAdvisor, Burdur Müzesi.

Makale Gönderme Tarihi: 16.02 .2020

Makale Kabul Tarihi: 13.04 .2020

\section{Önerilen Atıf:}

Sop, S. A., Ongun, U. ve Abalı, R. (2020). Müze Deneyimini Etkileyen Unsurlar: Çevrimiçi Yorumlar Üzerine Nitel Bir Araştırma, Türk Turizm Araştırmaları Dergisi, 4(2): 1123-1138.

(C) 2020 Türk Turizm Araştırmaları Dergisi. 


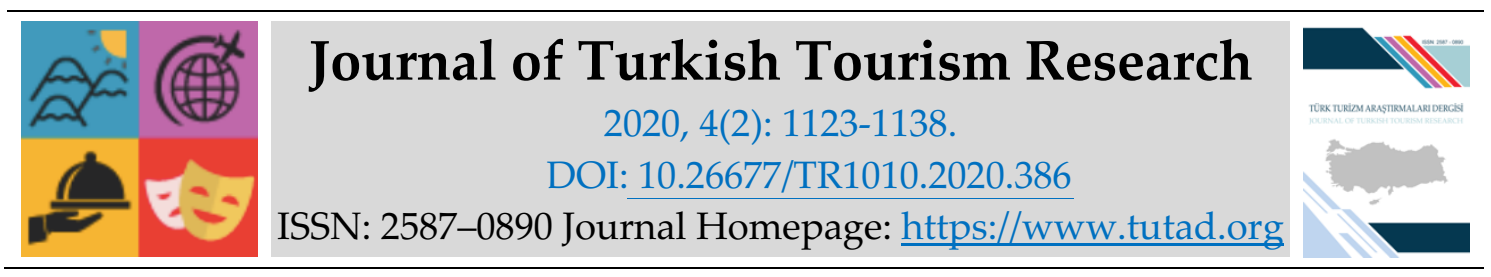

RESEARCH PAPER

\title{
Factors Affecting the Museum Experience: A Qualitative Research on Online Reviews
}

Assistant Prof. Dr. Serhat Adem SOP, Burdur Mehmet Akif Ersoy University, School of Tourism and Hotel Management, Burdur, e-mail: serhatademsop@gmail.com

ORCID: https://orcid.org/0000-0001-9096-9496

Assistant Prof. Dr. Utku ONGUN, Burdur Mehmet Akif Ersoy University, School of Tourism and Hotel Management, Burdur, e-mail: utkuongun@mehmetakif.edu.tr

ORCID: https://orcid.org/0000-0002-0722-6382

Rıdvan ABALI, Graduate Student, Burdur Mehmet Akif Ersoy Üniversitesi, Social Sciences Institute, Burdur, e-mail: ridvan.abali@outlook.com

ORCID: https://orcid.org/0000-0001-9408-971X

\begin{abstract}
Applying the qualitative approach, this study has been carried out to determine the factors which affect individuals' museum experience positively and negatively. Within this context, all of the online reviews about Burdur Museum which were shared on TripAdvisor between 11.12.2012 11.11.2019 have been examined and a total of 135 reviews including visitors' evaluations related to museum experience were subjected to content analysis. The obtained qualitative data have been analyzed by using MAXQDA software. As a result of the research, 10 sub-dimensions have been determined as the factors supporting positive museum experience. These dimensions are "the evocation of the ancient city, quality of the monuments and sculptures, the concerned staff, ease of transportation, interior design, descriptors and signs, the surrounding spaces, suitability for disabled people, cleanliness and maintenance, contemporary museum approach". The factors negatively affecting the museum experience of the visitors have been explained in four subcategories namely "having a small museum area, insufficient informational materials, enlightening problems, the lack of a sales store". In parallel with the results of the research, evaluations have been made for museum administrators and future research.
\end{abstract}

Keywords: Museum Experience, Online Visitor Reviews, TripAdvisor, Burdur Museum.

Received: 16.02 .2020

Accepted: 13.04 .2020

Suggested Citation:

Sop, S. A., Ongun, U. and Aball, R. (2020). Factors Affecting the Museum Experience: A Qualitative Research on Online Reviews, Journal of Turkish Tourism Research, 4(2): 1123-1138.

(c) 2020 Türk Turizm Araştırmaları Dergisi. 


\section{Gíriş}

Müzeler, insanlık tarihinin oluşturduğu mirası koruyan, araştıran ve ziyaretçilerin eğitim, iş ve eğlence gibi deneyimler edinebilmesi için sergileyen, böylece topluma ve toplumun gelişmesine yönelik hizmet veren halka açık mekânlardır (Kandemir ve Uçar, 2015). Bu mekânlar; miras ve kültürün korunması, miras hakkındaki bilginin yayılması, yerel halkın yanı sıra turistlerin bölgeye çekilmesi gibi çeşitli işlevleri yerine getirmektedir (Trinh ve Ryan, 2013). Turizm destinasyonlarının en popüler çekicilikleri arasında yer alan müzeler (McKercher, 2004), şehir turizmi açısından da oldukça önemli birer çekim merkezi olarak değerlendirilmektedir (JansenVerbeke ve Van Rekom, 1996). Arkeoloji, sanat ve oyuncak gibi çeşitli temalar altında faaliyet gösteren bu mekânlar her yıl milyonlarca kişi tarafından ziyaret edilmektedir. Bu ziyaretçilerin temel beklentisi ise hiç şüphesiz keyifli ve öğretici bir müze deneyimi yaşamaktır. Müzelerin deneyim odaklı mekânlar olduğunu savunan Prentice (1996: 169) bu alanları; "ziyaretçilerin kişisel gözlem yapabildikleri ya da temas edebildikleri kültür miraslarını bulunduran farklı birçok mekân gibi, kişilerin deneyimlerini daha kolay bir hale getirmek için oluşturulmuş yapılar, deneyimsel ürünler" olarak tanımlamaktadır. Bu bağlamda, farklı deneyimler yaşamak isteyen ziyaretçi gruplarını anlayabilmek ve onların beklentilerini karşılayabilmek, müzelerin etkili bir şekilde yönetilebilmesi için gereklilik haline gelmektedir (Moscardo, 1996; Kang ve Gretzel, 2012; Sop vd., 2019).

Ziyaretçilerin müze deneyimleri üzerine yürütülen araştırmalarda genellikle deneyimin ziyaretçi memnuniyeti, tekrar ziyaret etme eğilimi ve başkalarına tavsiye etme niyeti ile ilişkisi tartışılmaktadır (Radder ve Han, 2015; Özer vd., 2013; Özer vd., 2014). Ancak, ziyaretçilerin müzeye yönelik tutum ve davranışlarını anlamak için müze deneyimini olumlu ve olumsuz etkileyen unsurların da irdelenmesi gerekmektedir. Her ne kadar bazı araştırmalarda müzelerin fiziksel çevresini oluşturan unsurlar (sergi alanı) bu açıdan tartışılsa da (Jeong ve Lee, 2006; Sop vd., 2019), müze deneyimini etkileyen unsurların derinlemesine anlaşılabilmesi için nitel paradigmanın benimsendiği araştırmalara da ihtiyaç duyulmaktadır. Buna ek olarak, sınırlı sayıda müze ziyaretçisiyle yüz yüze görüşme yapmak yerine, günümüzde turistik deneyimlerin aktif biçimde paylaşıldığı çevrimiçi platformlardaki ziyaretçi yorumlarının incelenmesi yoluyla daha çok ziyaretçinin müze deneyimini anlamak mümkün olabilmektedir. Buradan hareketle mevcut araştırmada, ziyaretçilerin müze deneyimini olumlu ve olumsuz etkileyen unsurların tespit edilmesi amaçlanmış, araştırmanın bağlamı olarak Burdur Müzesi seçilmiştir. Çünkü Türkiye'nin önde gelen müzeleri arasında kabul edilen Burdur Müzesi'nde ziyaretçilerin müze deneyimini etkileyen unsurların henüz tartışılmadığı görülmektedir. TripAvisor platformunda müzeyle ilgili paylaşılan yorumlar ise araştırmanın veri seti olarak kabul edilmiş ve içerik analiziyle çözümlenmiştir. Bilindiği üzere TripAdvisor, kullanıcılar tarafından seyahat ve turizm bağlamında içerik oluşturulabilen dünyanın en popüler web sitesidir (Lu ve Stepchenkova, 2015). Bu nedenle, TripAdvisor platformu ve burada yazılan çevrimiçi yorumlar turizm araştırmacıları tarafından güvenilir veri kaynağı olarak kabul edilmektedir (Ayeh vd., 2013; Çuhadar vd., 2017; Çuhadar vd., 2018; Çuhadar ve Aşıroğlu., 2019; İnanır ve Ongun, 2019; Kladou ve Mavragani, 2015; Lupu vd., 2017; Stoleriu vd., 2019). Burdur Müzesi ziyaretçilerinin müze deneyimini olumlu ve olumsuz etkileyen unsurların belirlenmesi neticesinde müze yönetimi için uygulanabilir öneriler geliştirilecektir. Diğer taraftan, mevcut araştırma probleminin ve bu doğrultuda uygulanan yöntemin gelecek araştırmalar için önemli bir perspektif sunacağı düşünülmektedir.

\section{MÜZE DENEYIMİ}

Müze ziyaretleri, tarihi ve sanatsal geziler olarak yorumlanmaktadır (Sheng vd., 2008). Seyahat/gezi kapsamında değerlendirilmesi nedeniyle ziyaretçilerin müze deneyimi bir anlamda 
turist deneyimi olarak da ifade edilebilmektedir (Hertzman vd., 2008; Sheng ve Chen, 2012). Ancak hem turist deneyimi hem de müze deneyimi olgularının özünde deneyimsel tüketim olgusu yer almaktadır. Pine ve Gilmore'un (1998) ileri sürdüğü ve günümüzde turizm sektörü açısından geçerliğini koruyan deneyim ekonomisi yaklaşımına göre; işletmeler tüketiciler için bireyselleştirilmiş ürünler sunmanın yanında uzun yıllar boyunca anımsayacakları hatıralar yaratabilme gayreti içerisindedir. Bu kapsamda tüketicilerin deneyimleri; eğlence, eğitim, estetik ve kaçış olmak üzere dört boyutta meydana gelmektedir. Tüketicilerin eğitim ve kaçış deneyimlerini yaşayabilmeleri için aktif katılım gerekirken, eğlence ve estetik deneyimler ise pasif katılım ile oluşabilmektedir. Bu bağlamda; televizyon izleme veya konsere gitme gibi eğlence türünde bir etkinliği ya da sinıfta derse girme gibi bir eğitim sürecini deneyimleyen bireyler etkinliğin dişında konumlanmaktadır. Ancak, bir etkinlikte çalgı aleti çalma veya kanyon yürüyüşü yapma gibi günlük rutinden kaçış deneyimini yaşayanlar ya da kanyon manzarasını izleme veya bir sanat galerisini ziyaret etme gibi estetik bir deneyim yaşayan bireyler daha çok etkinliğin merkezi konumunda yer almaktadır (Pine ve Gilmore, 1998).

Pine ve Gilmore'un (1998) deneyim olgusuna bakışı müze deneyimini açıklama hususunda da kabul edilmektedir. Bu bağlamda Radder ve Han (2015), Pine ve Gilmore'un (1998) deneyim ekonomisi ve dört boyutlu deneyim yaklaşımının müze ziyaretçileri açısından da geçerli olduğunu savunmaktadır. Yazarlara göre müzeler bireylere eğitim deneyimini yaşatan mekânlardır. Bu mekânları ziyaret eden bireyler eserler hakkında bilgi sahibi olmakta ve farkındalık geliştirebilmektedir. Müze ziyaretleri çoğu zaman eğlenceli bir deneyim olarak da yorumlanmaktadır. Bireylerin günlük hayatın temposundan kaçış için katıldıkları etkinlikler arasında yine müze ziyaretleri bulunmaktadır. Bunların yanı sıra müzeler, estetik deneyimin oldukça yoğun yaşandığı mekânlardır. Çünkü ziyaretçiler müzelerde sergilenen eserleri incelerken müzenin fiziksel çevresini ve genel atmosferini de duyusal açıdan değerlendirmektedir (Radder ve Han, 2015). Bu kapsamda yürütülen bir araştırmada, müze ziyaretçilerinin eğlence veya kaçı̧tan ziyade eğitim ve estetik deneyimlerinin müze memnuniyeti üzerinde anlamlı bir etkiye sahip olduğu belirlenmiştir (Mehmetoglu ve Engen, 2011). Bazı araştırmalarda ise müzelerde estetik deneyimi oluşturan fiziksel çevre unsurları ile ziyaretçilerin müze memnuniyeti arasında anlamlı bir etkileşim tespit edilmiştir (Jeong ve Lee, 2006; Sop vd., 2019). Uzun giriş kuyrukları, sergilenen eserlerin rahatça görülememesi ve oturma/dinlenme alanlarının bulunmaması gibi müze deneyimini etkileyen fiziksel çevreyle ilgili sorunların ise ziyaretçi memnuniyetini olumsuz etkilediği ileri sürülmektedir (Brida vd., 2013).

Müzeler eğitim, estetik, eğlence ve kaçış deneyimlerinden birini ya da birkaçını yaşamak isteyen bireyler tarafından ziyaret edilmektedir. Bu durumda söz konusu bireylerin müze deneyimine ilişkin çeşitli beklentileri ortaya çıkabilmektedir. Örneğin, Tayvan'da yapılan bir araştırmada özellikle yüksek eğitim düzeyinde yer alan kadın ziyaretçilerin rahatlık ve eğlence beklentisi içerisinde oldukları; evli ve yaşlı ziyaretçilerin ise daha çok tarihi hatıra beklentisiyle müze ziyaretini gerçekleştirdikleri belirlenmiştir (Sheng ve Chen, 2012). Mevlana Müzesi üzerine yapılan bir araştırmada ise ziyaretçilerin müze deneyiminden beklentileri; ilgi ve empati, kültürel etki, hayal kurma, hatıra, ödediğinin karşılığını alma şeklinde tanımlanmıştır (Özer vd., 2013) Böylece, ziyaretçilerin müze deneyiminden beklentilerini açıklamak üzere yürütülen farklı araştırmalarda Pine ve Gilmore'un (1998) deneyim sınıflamasının genişletilebileceği anlaşılmaktadır. Bu kapsamda yapılan bazı çalışmalarda akışa kapılma, nostalji, sosyalleşme ve kültürel kimliğe kavuşma gibi farklı müze deneyimi boyutlarının ortaya çıtığı ifade edilmektedir (Kırcova ve Erdoğan, 2017). 




Fotoğraf 1. Burdur Müzesi

Kaynak: Türkiye Kültür Portalı (2020)

Mevcut çalışmanın araştırma bağlamı olan Burdur Müzesi (bkz. Fotoğraf 1), Burdur şehrinin merkez ilçesinde yer almaktadır. Afyon, Antalya, Denizli ve Isparta ile sınır komşusu olan Burdur şehri, tarihsel olaylar açısından İç Anadolu, Ege ve Akdeniz uygarlıklarından izler taşımaktadır. Baradız, Hacılar ve Kuruçay'daki arkeolojik çalışmalar, şehrin Prehistorik, Paleolitik, Neolitik, Kalkolitik, Tunç ve Demir çağlarına kadar uzanan bir geçmişe sahip olduğunu göstermektedir (Duru, 2008; Sevin, 2013). Burdur şehrinde Pers, Hellen, Roma, Bizans, Selçuklu ve Osmanlı dönemlerine ait izler de tescillenmiş durumdadır (Sevin, 2013). Bu bağlamda, derin bir tarihi ve arkeolojik zenginliğe sahip olan Burdur şehrindeki ilk müze kurma girişimi 1956 yılında gerçekleşmiştir (Yılmaz, 2005). 2001 yılında yeniden düzenlenen, 2006 yılında ziyarete açılan, 2008 yılında ise Gezilip Görülmeye Değer Müze ödülünü alan Burdur Müzesi; Hacılar, Höyücek ve Kuruçay Höyükleri ile Sagalassos, Kibyra ve Kremna'daki arkeolojik kazı çalışmalarından çıkarılan ya da satın alma ve bağış yoluyla elde edilen yaklaşık 60.000 eserin sergilendiği bir arkeoloji müzesidir. Burdur Müzesi; arkeolojik ve tarihsel araştırma yapanlar, arkeolojik eserlere ilgi duyanlar ve tarihsel perspektifte uzun ve keyifli, bir o kadarda bilgi dolu bir yolculuğa çıkmak isteyenler için oldukça ideal bir mekândır (Sop vd., 2019). Bu çerçevede, müzenin ziyaretçilerine eğitim, eğlence, estetik ve kaçış gibi farklı deneyimler sunabilecek nitelikte bir turistik mekân olduğu ileri sürülebilmektedir.

\section{YÖNTEM}

2019 yılında 33053 kişi tarafından ziyaret edilen (Kültür ve Turizm Bakanlığı Döner Sermaye İşletmesi Merkez Müdürlüğü, 2019) ve Türkiye'nin önde gelen müzeleri arasında kabul edilen Burdur Müzesi'nde ziyaretçilerin müze deneyimini etkileyen unsurların henüz tartışılmadığı görülmektedir. Sop vd.'nin (2019) araştırmasında Burdur Müzesi'nin fiziksel çevre unsurlarının müze memnuniyetine etkisi sorgulanmış olsa da ziyaretçi deneyimini etkileyebilecek pek çok unsur ilgili araştırmada tanımlanmamıştır. Diğer taraftan müze deneyimini etkileyen unsuları daha kapsamlı biçimde tartışabilmek için nicel tasarım yerine nitel tasarımın uygulandığı bir araştırmaya ihtiyaç duyulmaktadır. Dolayısıyla mevcut araştırma; "ziyaretçilerin müze deneyimini olumlu ve olumsuz etkileyen unsurlar nelerdir?" sorusunu yanitlamak üzere Burdur Müzesi bağlamında yürütülmüştür. Araştırmanın amacı doğrultusunda, sınırlı sayıda müze ziyaretçisiyle yüz yüze görüşme yapmak yerine, günümüzde turistik deneyimlerin aktif biçimde 
paylaşıldığı çevrimiçi platformlardaki ziyaretçi yorumlarının incelenmesine karar verilmiştir. Böylece daha çok ziyaretçinin müze deneyimini anlama imkânı sağlanabilmiştir. Bu kapsamda, TripAdvisor platformunda Burdur Müzesi ile ilgili yapılmış olan çevrimiçi yorumlar incelenmiş ve 11.12.2012 - 11.11.2019 tarihleri arasında müzeyi ziyaret etmiş olan bireylerin müze deneyimine yönelik olumlu ya da olumsuz değerlendirmelerini içeren tüm yorumlar (135 yorum) içerik analizine tabi tutulmuştur. Nitel veri çözümleme aşamasında MAXQDA yazılımından yararlanılmış ve yorumlarda en çok tekrar eden sözcükler belirlenmiştir. En çok tekrar eden sözcükler ve içerik analizi sonucunda müze deneyimini etkileyen unsurlar olumlu ve olumsuz unsurlar şeklinde iki tema altında yorumlanmıştır. Bulguların, diğer bir ifadeyle deneyimi olumlu ve olumsuz etkilediği belirlenen unsurların, desteklenmesi için bazı ziyaretçilerin söz konusu temayla ilişkili çevrimiçi yorumları doğrudan alıntı yapılarak metne aktarılmıştır.

\section{BULGULAR}

Burdur Müzesi'ni ziyaret etmiş olan bireylerin müzeye yönelik olumlu ya da olumsuz değerlendirmelerini içeren 135 yorum; Türkçe (99 yorum), İngilizce (24 yorum), Rusça (6 yorum), Almanca (1 yorum), İspanyolca (1 yorum), Fransizca (1 yorum), İtalyanca (1 yorum), Japonca (1 yorum) ve Felemenkçe (1 yorum) dillerinde yazılmıştır. Gerçekleştirilen ziyaretler sonrasında Burdur Müzesi hakkında yapılan genel değerlendirme sonuçlarına Tablo 1'de yer verilmiştir. Tabloda da görüldüğü üzere, Burdur Müzesi'nin yerli ve yabancı ziyaretçilerinin neredeyse tamamı müzeye karşı olumlu bir tutum sergilemektedir. Diğer taraftan, müzeyi kötü ya da berbat derecesinde olumsuz olarak değerlendiren hiçbir ziyaretçinin olmadığı görülmektedir.

Tablo 1. Burdur Müzesi Ziyaretçilerinin Çevrimiçi Değerlendirmelerinin Dağılımı

\begin{tabular}{lccc}
\hline & Verilen Puan & $n$ & $\%$ \\
\hline Mükemmel & 106 & 80 \\
Çok İyi & 25 & 18 \\
Ortalama & 4 & 2 \\
Kötü & 0 & 0 \\
Berbat & 0 & 0 \\
& Toplam & 135 & 100 \\
\hline
\end{tabular}

Genel değerlendirmeye ilişkin dağılımın ardından, çevrimiçi yorumların tamamı içerik analizine tabi tutularak en çok tekrar eden sözcükler belirlenmiştir. Bu aşamada MAXQDA programından faydalanılarak bir sözcük bulutu oluşturtulmuştur. Şekil 1'de sunulan sözcük bulutu incelendiğinde; müze, Sagalassos, Burdur, heykeller, mükemmel, mutlaka, antik, eserler, arkeoloji, harika gibi baskın sözcükler dikkat çekmektedir. Sözcük bulutu oluşturulurken "bir, için, kadar, ve, ancak" gibi kapsam dişı sözcükler analize dâhil edilmemiştir. 


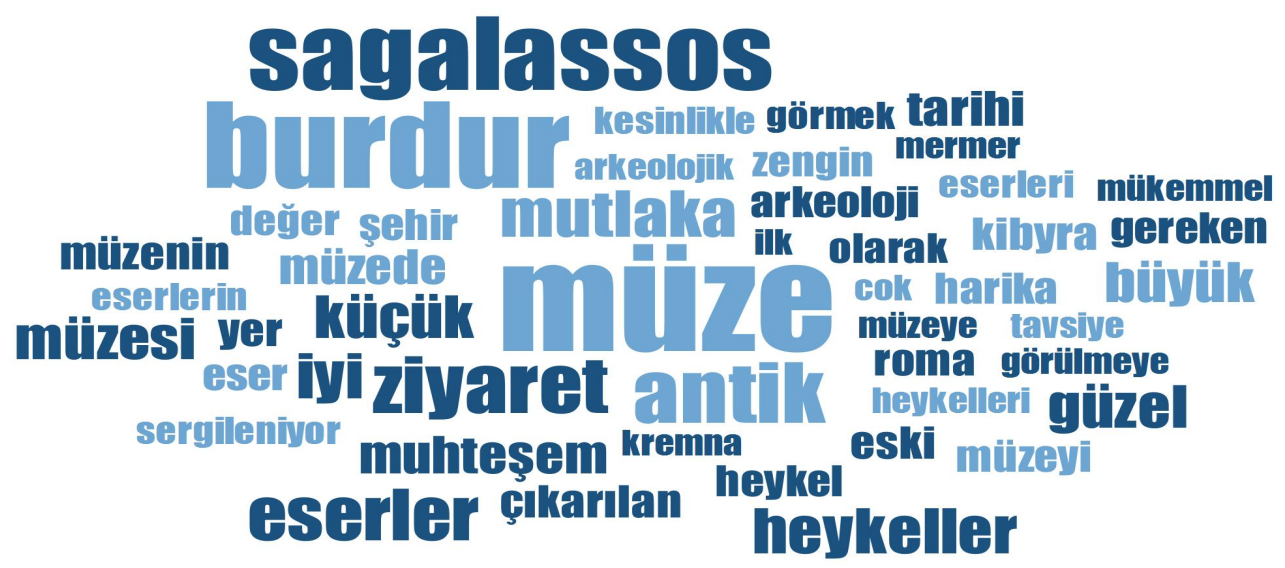

Şekil 1. Çevrimiçi Yorumlardan Elde Edilen Sözcük Bulutu

Şekil 1'de öne çıkan sözcükler Burdur Müzesi ziyaretçilerinin çevrimiçi yorumlarında en çok vurgulanan unsurları göstermektedir. Bunların detaylı dağılımı ise Tablo 2'de sunulmuştur. Sözcük analizi aşamasında aynı kavramı ifade eden sözcükler birleştirilmiştir (örneğin, heykeller + heykel = heykel; müzenin + müzede + müze $\ldots=$ müze). Bu bağlamda, 135 çevrimiçi yorumda toplam sözcük sayısının 5718 olduğu, en çok tekrar eden 25 sözcügün ise toplam sözcük sayısının \%17.93'ünü oluşturduğu belirlenmiştir ( $\mathrm{n}=1025)$. En çok kullanılan 25 sözcük genel olarak incelendiğinde, ziyaretçi yorumlarında en sık kullanılan ifadenin "müze" olduğu ( $n=174, \% 3,04)$, Burdur Müzesi ile ilgili olumlu ifadelerin kullanıldığı ve gerek şehrin gerekse şehirdeki diğer turistik çekiciliklerin (Sagalassos ve Kibyra antik kentleri gibi) müzeye yönelik çevrimiçi yorumlarda vurgulandığı tespit edilmiştir.

Tablo 2. Çevrimiçi Yorumlarda En Çok Kullanılan 25 Sözcük (N=5718)

\begin{tabular}{|c|c|c|c|c|c|}
\hline Sözcük & $n$ & $\%$ & Sözcük & $n$ & $\%$ \\
\hline 1. Müze & 174 & 3,04 & 14. Büyük & 27 & 0,47 \\
\hline 2. Çok & 89 & 1,56 & 15. Muhteşem & 25 & 0,44 \\
\hline 3. Burdur & 85 & 1,49 & 16. Tarihi & 21 & 0,37 \\
\hline 4. Sagalassos & 70 & 1,22 & 17. Bulunan & 19 & 0,33 \\
\hline 5. Eser & 59 & 1,03 & 18. Kibyra & 19 & 0,33 \\
\hline 6. Antik & 53 & 0,93 & 19. Yer & 19 & 0,33 \\
\hline 7. Ziyaret & 49 & 0,86 & 20. Burada & 18 & 0,31 \\
\hline 8. Mutlaka & 36 & 0,63 & 21. Çıkarılan & 18 & 0,31 \\
\hline 9. Heykel & 51 & 0,89 & 22. Eski & 18 & 0,31 \\
\hline 10. İyi & 33 & 0,58 & 23. Gereken & 17 & 0,30 \\
\hline 11. Güzel & 32 & 0,56 & 24. Arkeoloji & 16 & 0,28 \\
\hline 12. Küçük & 32 & 0,56 & 25. Harika & 16 & 0,28 \\
\hline 13. Daha & 29 & 0,51 & Toplam & 1025 & 17,93 \\
\hline
\end{tabular}

Burdur Müzesi ziyaretçilerinin müze deneyimini olumlu ve olumsuz etkileyen unsurları belirlemek üzere tüm çevrimiçi yorumlar incelenmiş ve ziyaretçilerin yorumları doğrultusunda iki temel kategoriyle birlikte 14 alt kategori oluşturulmuştur. Tablo 3'te sunulan bu bulgulara göre Burdur Müzesi; “antik kent çağrışımı, eser ve heykellerin niteliği, ilgili personel, ulaşım kolaylığı, iç tasarım, açıklayıcı ve işaretler, çevredeki mekânlar, engelli bireylere uygunluk, temizlik ve bakım, çağdaş müzecilik anlayışı" olmak üzere toplam 10 alt kategoride olumlu bir deneyim sunmaktadır. Ziyaretçi yorumlarına göre müze deneyimini olumsuz etkileyen unsurlar 
ise "alanın küçük olması, bilgilendirme materyallerinin yetersizliği, aydınlatma sorunları, satış mağazasının bulunmaması" şeklindedir. Tablo 3'te yer alan kategorilerin ziyaretçi deneyimine etkisini açıkça ortaya koymak amacıyla bazı ziyaretçi yorumları doğrudan alıntı yapılarak tablonun ardından sunulmuştur. Ziyaretçi yorumları Z1 ile Z135 arasında kodlar verilerek metne aktarılmıştır.

Tablo 3. Burdur Müzesi'nde Ziyaretçi Deneyimini Etkileyen Unsurlar

\begin{tabular}{ll}
\hline \multicolumn{1}{c}{ Kategoriler } & \multicolumn{1}{c}{ Alt Kategoriler } \\
\hline & 1. Antik Kent Çağrışımı \\
2. Eser ve Heykellerin Niteliği & 3. İlgili Personel \\
& 4. Ulaşım Kolaylı̆̆ı \\
5. İç Tasarım \\
6. Açklayııılar ve İşaretler \\
7. Çevredeki Mekânlar \\
8. Engelli Bireylere Uygunluk \\
9. Temizlik ve Bakım \\
10. Çağdaş Müzecilik Anlayışı \\
\\
1. Alanın Küçük Olması \\
2. Bilgilendirme Materyallerinin Yetersizliği \\
3. Aydınlatma Sorunları \\
4. Satış Mağazasının Bulunmaması
\end{tabular}

Bir arkeoloji müzesi olan Burdur Müzesi'ni ziyaret eden bireylerin aşağıdaki çevrimiçi yorumları incelendiğinde, özellikle Sagalassos Antik Kenti ile Burdur Müzesi'nin birbirlerini tamamlayan birer turistik çekicilik olduğu ve bu çağrışımın ziyaretçi deneyimini derinleştirdiği anlaşılmaktadır. Bu kapsamdaki yorumlardan hareketle, Burdur Müzesi'nin müzede sergilenen eserlerin çıkarıldığı antik kenti başarıyla çağrıştırdığı ve ziyaretçilerinin bu mekânları ziyaret etme motivasyonunu güçlendirdiği sonucuna ulaşılmaktadır:

"Özellikle Sagalossos antik şehri gezildikten sonra mutlaka görülmesi gerekir bence. Çünkü birbirini tamamlıyor. Sagalasos'dan çıkan eserler bu müzede. İkincisi de Kibyra da buradan sonra ya da öncesinde gezilirse daha mükemmel" (Z7).

"Sagalassos ile birlikte Burdur müzesi mutlaka gezilmeli" (Z16).

"Sagalassos antik kenti gezisinden sonra Burdur Müzesini gezdik ve kazıda çıkan ve bazılarının kopyaların ören yerinde gördüğ̈̈müz heykellerin asılların gördük" (Z73).

"Gezinin daha doyurucu olmasım isterseniz lütfen ören yerlerinden önce müzeyi gezin" (Z85).

"Müze mükemmel ve Sagalassos'u ziyaret ettikten sonra bu mutlaka görülmeli" (Z114).

Tablo 3'e göre Burdur Müzesi'nde sergilenen eserlerin çekiciliği ziyaretçilerin müze deneyimi üzerinde olumlu bir etki yaratmaktadır. Bu kapsamdaki çevrimiçi yorumlardan hareketle, özellikle eser ve heykellerin büyüklüğü, bunların korunarak günümüze ulaştırılmış olması, eserlerin yapımında sergilenen işçilik performansı gibi hususlar eser ve heykellerin niteliği 
kapsamında değerlendirilmiştir. Bu alt kategoriye yönelik ziyaretçi yorumlarından hareketle müzede sergilenen mevcut eserlerin müze deneyimini olumlu etkilediği tespit edilmiştir:

"... birinci sını mermer heykeller bulunmaktadır. Heykeller muhteşem o mermerleri nasıl işlediklerine, ne kadar sürede işlediklerini anlamak mümkün değil" (Z9).

"Eserler oldukça güzel ve daha önce müzede görmediğim boyutlarda büyükler" (Z10).

"Roma imparatoru Hadrianus'un başı dev ayak heykelleri görülmeye değer" (Z19).

"Eserler oldukça etkileyici" (Z28).

"Eserlerin her biri birbirinden değerli, keyifli bir müze ziyaretiydi..." (Z35).

"Çoğu eser dünyada tek örnektir" (Z52).

"... o harika eserler görülmeli. Heykeller ve mermer işçiliği harika ..." (Z55).

"Sagalassos antik şehrinin muhteşem heykelleri karşısında gözleriniz kamaşacak" (Z92).

"Heykeller çok iyi korunmuş durumda ..." (Z104).

"Mermer heykeller inanilmaz" (Z118).

Burdur Müzesi çalışanlarının ziyaretçi deneyimi üzerindeki etkisini yorumlamak üzere yapılan incelemede, müze personelinin sergilediği yardımseverlik ve güler yüzlü iletişim kurma gibi olumlu davranışların ziyaretçi memnuniyetini arttırdığı belirlenmiştir. Bu kapsamdaki bazı çevrimiçi yorumlar şöyledir:

"Çalışan görevliler çok yardımcı ve ilgili" (Z 13).

"Çalışan arkadaşlar güler yüzlü ve dikkatliler. Görevlerini iyi yapıyorlar" (Z71).

"Görevli personelleri güler yüzlü ve yardımseverler" (Z89).

"... personelin hepsi cana yakın ve yardımseverdir, küçük gizli köşeleri kaçırmamanızı sağlar" (Z121).

Merkezi bir konumda bulunan Burdur Müzesi'nin ulaşım olanaklarının ziyaretçiler tarafından olumlu algılandığı aşağıdaki yorumlarda açıkça görülmektedir. Bu kapsamda, ulaşım kolaylığının müze deneyimi açısından önemli bir unsur olduğu anlaşılmaktadır:

"... Ağlasun üzerinden yol gayet iyi 1,5 saat ayırını" (Z18).

"Tarih kokan Burdur müzesi yeri konumu itibariyle ulaşımı kolay ..." (Z27).

"Müzeye ulaşım çok kolaydır. Müze Burdur'un tek caddesi olan Gazi Caddesi üzerinde yer alır" (Z52).

"Müzenin yeri oldukça merkezi, bu sayede ulaşımı kolay" (Z72).

"Kolay ulaşabileceğiniz, Burdur'a varınca zorlanmadan bulup rahatlikla gezebileceğiniz güzel bir müze" (Z93).

"Burdur şehir merkezinde bulunur ve erişimi kolaydır" (Z110).

Müzenin iç tasarım açısından nasıl değerlendirildiği ve tasarım özelliklerinin ziyaret deneyimiyle ilişkisi incelendiğinde, eserlerin kronolojik şekilde sıralanmış olması, başarılı iç mekan düzenlemesi ve mekanın genel anlamda iyi organize edilmiş olmasının müze deneyimini olumlu etkilediği belirlenmiştir:

"Müzenin iç dizaynı akıllıca" (Z38). 
"Burada eserler kronolojik bir straya göre düzenlenmiştir" (Z49).

"Etrafındaki kültürel değerleri antik unsurları barındıran çok değgrli bir müze çok iyi organize olmuş çok başarılı" (Z54).

"Müze çok güzel tasarlanmış, muhteşem heykeller ve diğer buluntular belirli bir düzende atlamadan gezilebiliyor" (Z66).

"İyi düzenlenmiş, ... Düzenli bir müze" (Z76).

"Çok düzenli ve iyi sergilenmiş eserler var" (Z83).

"Eser yerleşimleri ile ışık düzenlemesi harika idi. Anadolu'da yaşayan kültürlerin buluntuları pek profesyonelce düzenlenmişti" (Z95).

"Müze çok iyi organize edilmiş" (Z100).

"Sunum çok büyüleyici; aydınlatma mükemmel ve iyi fotoğraflar çekmenizi sağlar" (Z108).

Çevrimiçi yorumlardan hareketle, müzede yer alan açılayıcı notların ve yönlendirme işaretlerinin ziyaretçiler açısından yeterli bulunduğu ve ziyaret deneyimi çerçevesinde olumlu değerlendirildiği anlaşılmaktadır. Bu bağlamda, özellikle yabancı ziyaretçilerin bilgi edinme ile yönlendirici işaretleri ve eserlerin açılamalarını anlama konusunda Burdur Müzesi'nden memnun oldukları tespit edilmiştir:

"Bilgi edinmek çok kolay. İşaretler açı ..." (Z102).

"Bu müzenin koleksiyonu çok zengin ve ilginç - açıklaması da İngilizce" (Z105).

"... tüm eserlerin Türkçe ve İngilizce dillerinde açıklayıcı notları var" (Z110).

"Yazılı açıklamalar herhangi bir yabancı ziyaretçi için net ve kolay anlaşılır..." (Z121).

Çevrimiçi yorumlardan ulaşılan bulgulara göre, müzenin çevresindeki dinlenme mekânları ve farklı mimari yapıların ziyaretçilerin müze deneyimini genişletmekte ve memnuniyet düzeyini olumlu etkilemektedir. Bu kapsamda, özellikle, müzenin hemen yanında faaliyet gösteren Müze Park kafeteryasının müze ziyaretçilerinin dinlenme ve yeme-içme ihtiyacını giderici nitelikte olduğu ve şehirdeki Ulu Camii ile diğer tarihi mekânların ziyaret motivasyonunu arttırdığı belirlenmiştir:

"Müzenin dışında, çay / kahve ve / veya bazı tatllar ile dinlenebileceğiniz Müze Parkı var" (Z122).

"Ziyaretiniz sona erdi hemen üste çıkın çayınızı söyleyin, gölgeliklerde serince oturun. Çeşitli içecekler mevcut. Ana caddeyle bitişik çay bahçesi" (Z36).

"Burdur'da iken, bir gün bile olsa, eski dolambaçlı sokaklarda Ulu Cami'ye kadar yürüyüşe değer. Eski Osmanlı dönemindeki evlerin çeşitli tamir durumlarında evleri, çeşitli taş ve kerpiç mimarileriyle büyüleyicidir" (Z117).

"Sadece birkaçını adlandırmak için: eski şehir mahallesi, modern şehir merkezinden tepenin hemen yukarısına; uzun süredir kaybolmuş Osmanlı Rumlarına (Türklerin "Rum" dedikleri - "Roma İmparatorluğu"nda olduğu gibi "Roma"dan) bir ibadet yeri olan eski ve boşta duran eski katedral ..." (Z119).

Ziyaretçi yorumlarından hareketle Burdur Müzesi'nin engelli bireyler için olumlu müze deneyimi yaşatabilecek nitelikte faaliyet gösterdiği belirlenmiştir. Bu kapsamda, özellikle tekerlekli sandalye kullanan bireylerin kullanabileceği rampa ya da uygun yolların yeterli nitelikte olduğu anlaşılmaktadır: 
"Tekerlekli sandalye kullananlar da çok rahat gezebilecek" (Z44).

"Büyük artı: engelli insanlar için kolaylık var (normalde Türkiye'de o kadar açık değil)" (Z105).

"Her şey, engelli insanlar için uygun donanıma sahiptir (uygun sürüşler, rampalar)" (Z125).

Ziyaretçilerin müzenin genel temizliği ve müzede sergilenen eserlerin bakımı konularını dikkate aldıkları ve Burdur Müzesi'ni bu açıdan olumlu değerlendirdikleri tespit edilmiştir. Bu kapsamdaki bazı ziyaretçi yorumları şöyledir:

"... çok temiz, iyi düzenlenmiş bir müze" (Z60).

"Olağanüstü bütünlükte çok etkileyici heykeller ve tertemiz ferah bir müzede güvenle korunan tarihi eserleri gördük ..." (Z62).

"Çoğu Sagalassos Antik Kent'ten alınmış güzel sanat eserleri ve tarihi yapıları bulunduran temiz, güzel dizayn edilmiş bir müze" (Z90).

Aşağıdaki gibi bazı ziyaretçi yorumları Burdur Müzesi'nin çağdaş müzecilik anlayışını benimseyen bir müze olduğunu göstermektedir. Müzenin çağdaş bir yaklaşımla yönetiliyor olması ziyaretçi deneyimini olumlu yönde etkilemekte ve ziyaretçilerin takdirini kazanmaktadır:

"A Ă̆rllkh olarak Sagalassos antik kentinden çıkarılan eserlere ev sahipliği yapan müze örnek müzecilik anlayışı ile her türlü takdiri hak ediyor" (Z21).

"... profesyonel müzecilik özellikleri taşıyan bir sanat merkezi" (Z22).

"İstanbul Arkeoloji Müzesi'ne bile eser bakımından olmasa da modern müzecilik bakımından fark atar" (Z97).

Tablo 3'te belirtildiği üzere, Burdur Müzesi'ni ziyaret eden bireylerin müze deneyimini olumsuz etkileyen bazı unsurlar da söz konusudur. Örneğin, Burdur Müzesi'nin küçük bir müze olması bu anlamda öne çıan temel olumsuzluk olarak değerlendirilmektedir. Bu kapsamda bazı ziyaretçilerin müzenin küçük olmasından rahatsızlık duyduğu ve bu sorunun aşılması gerektiği yönünde görüş belirttiği tespit edilmiştir:

"Alanı küçük olduğu için maalesef eserlerin az bir kısmı sergileniyormuş" (Z14).

"Çok büyük olmamakla birlikte önemli eserler var" (Z31).

"Müze büyük olmasa da bence az ama öz eserler var" (Z72).

"Aslında daha büyük bir müze olmasını isterdim. Yapı olarak iki katlı ufak bir bina..." (Z78).

"Burdur Müzesi küçük bir alana sıkışmış bence" (Z83).

"Çok büyük değil ..." (Z118).

"Küçük bir müze, ancak görüntüler güzelce sunuldu..." (Z124).

Ziyaretçi yorumlarına göre Burdur Müzesi'ni ziyaret eden bazı bireyler eserlerin bilgilendirme notların yetersiz bulmakta ya da elektronik rehber gibi bir hizmet eksikliğini işaret etmektedir. Bazıları ise müzeyi anlatan bir broşür, el kitabı ya da dergi şeklindeki bir kaynağın sunulmamasını eleştirmektedir. Bu bağlamda, müzenin bilgilendirme hizmetinde aksaklıklar yaşandığı anlaşılmaktadır:

"Katalog kitap, Sagalassos veya Kibyra üzerine yazılmış hiçbir kaynak satılmıyor olması şaka gibi ve çok utandırıcı" (Z17). 
"... vitrinlerin içerisindeki ürünlerin bilgi kartları çok küçük yazılmış bunun için bu ürünlerin adının ne olduğunu, ne işe yaradığını, ne zamandan kaldığını öğrenmek biraz zorlayici oluyor" (Z48).

"Ancak müzede hiçbir simülasyonun olmaması dönemi anlamayı zorlaştırıyor. Yazılardan okuduğum bilgiler çok şey katsa da internetten edinebileceklerimin ötesine geçemiyor ve müzeyi daha sıkıcı hale getiriyor. Rehber olmadan gezilmez bunun yanında müzede elektronik rehber dahi satılamıyor. Buradan müze yöneticilerine önerim: Her eserin başına bir karekod koyarak eser hakkında bilgiye ulaşılabilir, yapılabilir" (Z81).

"Müzeyi anlatan kitap yok. Bu da başka bir konu" (Z87).

"Temsil edilen eserler ve müzenin kendisi hakkında kitap bulunmadığı için hayal kırıklığına uğradık, şiddetle bir broşür olması tavsiye edilir" (Z122).

Ziyaretçi yorumları incelendiğinde, müzenin aydınlatma açısından genel olarak olumsuz değerlendirildiği belirlenmiştir. Bu kapsamda, müze deneyimini olumsuz yönde etkileyen temel aydınlatma sorunlarının kısa süreye ayarlanmış fotoselli ışıklardan ve eserleri incelerken ortaya çıkan parlamadan kaynaklandı ̆̆ tespit edilmiştir.

"Pek çok müzemiz gibi biraz ışıklandırma ve okunamayan (parlama ve küçük boyut yüzünden) tabela problemi var" (Z83).

"Müzeye dair hoşlanmadığım tek detay fotoselli aydınlatmaların tam bir şeyi incelerken aniden sönmeleri ve yeniden yanmalar için biraz uğraşmanızın gerekmesiydi" (Z89).

"... aydınlatma da fotosel nedeni ile biraz sorun varsa da eserlerin hatırına ses çıkartılmaya bilinir" (Z99).

Tablo 3'te de görüldüğü gibi müze deneyimini olumsuz etkileyen unsurların sonuncusu Burdur Müzesi'nin ziyaretçilerine hizmet veren bir satış mağazasının bulunmamasıdır. Müze ziyaretçilerinin hediyelik ya da hatıra amaçlı ürünlere ulaşamaması nedeniyle ortaya çıkan hoşnutsuzluk bazı çevrimiçi yorumlarda şu şekilde ifade edilmiştir:

"Ne yazık ki çoğu taşra müzesi gibi burada da müze mağazası yok" (Z53).

"Ne yazık ki müzenin bir dükkanı yok" (Z111).

"Katalog kitap, Sagalassos veya Kibyra üzerine yazılmış hiçbir kaynak satılmıyor olması şaka gibi ve çok utandırıcı" (Z17).

"Ne yazık ki müze dükkânı ya da satılık müze kitabı yok ama en azından tüm sergilerin

Türkçe ve İngilizce olarak açıklayıcı notları var" (Z110).

\section{SONUÇ VE ÖNERİLER}

Bireylerin müze deneyimini etkileyen unsurları belirlemek üzere yürütülen bu araştırmada, Burdur Müzesi'ni ziyaret eden ve ziyaret deneyimine ilişkin değerlendirmelerini TripAdvisor platformunda paylaşan 135 bireyin çevrimiçi yorumları incelenmiştir. Ziyaretçilerin yorumları içerik analizine tabi tutularak çözümlenmiştir. Bu kapsamda, ilk olarak, Burdur Müzesi'ni ziyaret eden bireylerin neredeyse tamamının müzeyi mükemmel veya çok iyi olarak tanımladığı, dolayısıyla müzeye karşı olumlu bir tutum sergilediği belirlenmiştir. Çevrimiçi yorumlarda en çok tekrar eden sözcükler incelendiğinde ise ziyaretçilerin müzeyle birlikte şehrin diğer turistik çekiciliklerine (örneğin, Sagalassos antik kenti) de vurgu yaptıkları ortaya çıkmıştır. Böylece, 
Burdur Müzesi deneyiminin hem müzeye hem de müzeyle ilişkisi olan şehirdeki diğer çekiciliklere yönelik tutumu güçlendirdiği sonucuna ulaşılmıştır.

Araştırmanın bağlamından hareketle ziyaretçilerin müze deneyimini olumlu ve olumsuz etkileyen unsurlar incelendiğinde toplam 14 kategori ileri sürülebilmektedir. Bunlardan 10 tanesi deneyimi olumlu etkileyen unsurlardır. Bu bağlamda, Burdur Müzesi'nin antik kent çağrışımı yaratması müze deneyimini açık bir biçimde etkilemektedir. İçerik analizinden ulaşılan bulgulara göre özellikle Sagalassos Antik Kenti ile Burdur Müzesi'nin birbirlerini tamamlayan birer turistik çekicilik olduğu ve bu çağrışımın ziyaretçi deneyimini derinleştirdiği anlaşılmaktadır. Sergilenen eser ve heykellerin niteliği (eserlerin ve heykellerin büyüklügü ve korunarak günümüze ulaştırılmış olması, eserlerin yapımında sergilenen işçilik performansı vb.) de olumlu müze deneyiminin bir bileşeni olmaktadır. Aynı zamanda, müze personelinin sergilediği yardımseverlik ve güler yüzlü iletişim kurma gibi ilgili personel tutum ve davranışları, müze ziyaretinden memnun kalınmasına etki ederek, deneyimin olumlu değerlendirilmesine neden olmaktadır. Yine, müzenin merkezi konumu sayesinde ortaya çıkan ulaşım kolaylığı, başarılı iç tasarımı (eserlerin kronolojik şekilde sıralanmış olması, başarılı iç mekân düzenlemesi ve mekânın genel anlamda iyi organize edilmiş olması), müzenin genelindeki açıklayıcı ve işaretçilerin yeterli ve anlaşılır bulunması, engelli bireylere uygunluk (rampa ve tekerlekli sandalyeye uygun yolların bulunması) niteliğini taşıması ve müze genelinde fark edilen temizlik ve bakım ziyaretçilerin deneyim kalitesini arttırmaktadır. Ayrıca, çevredeki mekânlar (kafeteryalar, farklı mimari ve tarihi özellikteki yapılar [Ulu Camii gibi]) ziyaretçilerin müze deneyimini genişletmekte ve ziyarete ilişkin memnuniyet düzeyini olumlu etkilemektedir. Son olarak, müzenin çağdaş müzecilik anlayışı ile yönetildiğinin ziyaretçiler tarafından hissedilmesi (profesyonel ve modern bir müze olarak algılama) ziyaretçilerin müze deneyimini olumlu değerlendirmelerine neden olmaktadır.

Araştırmada ulaşılan bulgulara göre Burdur Müzesi ziyaretçilerinin müze deneyimini olumsuz etkileyen unsurlar dört kategori altında yorumlanabilmektedir. Bunlardan ilki alanın küçük olmasıdır. Bu bağlamda, bazı ziyaretçilerin müzenin küçük olmasından rahatsızlık duyduğu ve bu sorunun aşılmasını istediği tespit edilmiştir. Müze, bilgilendirme materyallerinin yetersizliği konusunda da bazı bireyler tarafından eleştirilmektedir. Eserlerin bilgilendirme notlarını yetersiz bulan ya da elektronik rehber gibi bir hizmetin eksikliğine atıfta bulunan bu ziyaretçiler müzenin bilgilendirme hizmetinde aksaklıklar yaşandığını ortaya koymaktadır. Ayrıca, kısa süreye ayarlanmış fotoselli ışıklardan ve eserleri incelerken ortaya çıkan parlamadan kaynaklanan aydınlatma soruları da bazı ziyaretçileri rahatsız edebilmektedir. Dolayısıyla, bu gibi sorun ve aksaklıklar müze deneyiminin olumsuz değerlendirilmesine sebep olabilmektedir. Son olarak, müzede bir satış mağazasının bulunmaması ziyaretçilerin hediyelik ya da hatıra amaçlı ürünlere ulaşabilmelerini engelleyerek genel bir hoşnutsuzluk yaratabilmektedir.

Mevcut araştırmanın sonuçlarına dayanılarak müze deneyiminin çok sayıda unsurdan etkilendiği ileri sürülebilmektedir. Bu durumda deneyimi olumlu etkileyen unsurlar müzelerin güçlü yönlerini yansıtırken, ziyaretçiler üzerinde olumsuz etki bırakan unsurlar ise müzelerin zayıf yönleri olarak değerlendirilebilir. Literatüre göre olumlu bir müze deneyimi; ziyaretçi memnuniyeti, tekrar ziyaret etme niyeti ve tavsiye etme niyeti üzerinde olumlu etkiler sergilemektedir (Radder ve Han, 2015; Özer vd., 2013; Özer vd., 2014). Bu bağlamda, müze yönetimlerinin deneyimi olumsuz etkileyen unsurları tespit ederek bu alanlardaki eksiklik ya da aksaklıkları gidermeleri ziyaretçilere olumlu bir deneyimin yaşatılabilmesi için önem arz etmektedir. Ayrıca, ziyaretçilerin deneyimsel beklentilerinin demografik değişkenlere göre anlamlı bir farklılık gösterdiğini bildiren çalışmalardan hareketle (Harman ve Akgündüz, 2014), gelecek araştırmalarda müze deneyimini olumlu ve olumsuz etkileyen unsurların demografik değişkenler açısından tartışılması önerilmektedir. 


\section{KAYNAKÇA}

Ayeh, J. K., Au, N. and Law, R. (2013). Do We Believe in TripAdvisor?": Examining Credibility Perceptions and Online Travelers' Attitude toward Using User-Generated Content, Journal of Travel Research, 52(4): 437-452.

Brida, J.G., Disegna, M. and Vachkova, T. (2013). Visitor Satisfaction at the Museum: Italian versus Foreign Visitors, BEMPS - Bozen Economics \& Management Paper Series, 2: 1-25.

Çuhadar, M. Köseoğlu, S. ve Gültepe, Ö. (2018). Isparta İlindeki Konaklama İşletmelerine Yönelik Çevrimiçi Müşteri Değerlendirmelerinin İncelenmesi: Tripadvisor Örneği, Süleyman Demirel Üniversitesi İktisadi ve İdari Bilimler Fakültesi Dergisi, 23(1): 227-239.

Çuhadar, M. ve Aşıroğlu, B. (2019). Zincir Fast-Food İşletmelerine Yönelik Çevrimiçi Değerlendirmelerin Analizi: Eskişehir Örneği, 20. Ulusal ve 4. Uluslararası Turizm Kongresi, 16-19 Ekim 2019, Eskişehir, ss: 415-422.

Çuhadar, M., Özkan, A. ve Çaylıkoca, A. (2017). Yiyecek İçecek İşletmelerine Yönelik Çevrimiçi Müşteri Değerlendirmelerinin İncelenmesi: Isparta İli Örneği, Süleyman Demirel Üniversitesi Sosyal Bilimler Enstitüsü Dergisi, 4(29): 33-48.

Duru, R. (2008). Burdur-Antalya Bölgesi'nin Altı Bin Yılı, Antalya: Sunan ve İnan Kıraç Akdeniz Medeniyetleri Araştırma Merkezi.

Harman, S. ve Akgündüz, Y. (2014). Efes Örenyeri Ziyaretçilerinin Müze Deneyimi Beklentilerini Belirlemeye Dönük Bir Araştırma, Gazi Üniversitesi İktisadi ve İdari Bilimler Fakültesi Dergisi, 16(2): $113-133$.

Hertzman, E., Anderson, D. and Rowley, S. (2008). Edutainment Heritage Tourist Attractions: A Portrait of Visitors' Experiences at Storyeum, Museum Management and Curatorship, 23(2): 155-175.

İnanır, A. ve Ongun, U. (2019). Yeşilova Salda'yı Ziyaret Eden Turistlerin Deneyimlerinin İncelenmesi, Türk Turizm Araştırmaları Dergisi, 3(4): 1028-1041.

Jansen-Verbeke, M. and Van Rekom, J. (1996). Scanning Museum Visitors: Urban Tourism Marketing, Annals of Tourism Research, 23(2): 364-375.

Jeong, J. H. and Lee, K. H. (2006). The Physical Environment in Museums and Its Effects on Visitors' Satisfaction, Building and Environment, 41(7): 963-969.

Kandemir, Ö. ve Uçar, Ö. (2015). Değişen Müze Kavramı ve Çağdaş Müze Mekanlarının Oluşturulmasına Yönelik Tasarım Girdileri, Türkiye Sosyal Araştırmalar Dergisi, 5(2): 17-47.

Kang, M. and Gretzel, U. (2012). Perceptions of Museum Podcast Tours: Effects of Consumer Innovativeness, Internet Familiarity and Podcasting Affinity on Performance Expectancies, Tourism Management Perspectives, 4: 155-163.

Kırcova, İ. ve Erdoğan, H. H. (2017). Müze Deneyimi Boyutları: İstanbul Oyuncak Müzesi Örneği, Uluslararası İktisadi ve İdari İncelemeler Dergisi, 16. UIKK Özel Sayısı: 649-664.

Kladou, S. and Mavragani, E. (2015). Assessing Destination Image: An Online Marketing Approach and the Case of TripAdvisor, Journal of Destination Marketing \& Management, 4(3): 187193. 
Kültür ve Turizm Bakanlığı Döner Sermaye İşletmesi Merkez Müdürlüğü. (2020). http://www.dosim.gov.tr/assets/documents/2019-ZIYARETCI-WEB-SITESI.pdf (Erişim Tarihi: 15.03.2020).

Lu, W. and Stepchenkova, S. (2015). User-Generated Content as a Research Mode in Tourism and Hospitality Applications: Topics, Methods, and Software, Journal of Hospitality Marketing $\mathcal{E}$ Management, 24(2): 119-154.

Lupu, C., Brochado, A. and Stoleriu, O. M. (2017). Experiencing Dracula's Homeland, Tourism Geographies, 19(5): 756-779.

McKercher, B. (2004). A Comparative Study of International Cultural Tourists, Journal of Hospitality and Tourism Management, 11(2): 95-107.

Mehmetoglu, M. and Engen, M. (2011). Pine and Gilmore's Concept of Experience Economy and Its Dimensions: An Empirical Examination in Tourism, Journal of Quality Assurance in Hospitality E Tourism, 12(4): 237-255.

Moscardo, G. (1996). Mindful Visitors: Heritage and Tourism, Annals of Tourism Research, 23(2): 376-397.

Özer, Ö., Avcı, U. ve Sop, S. A. (2014). İnanç Turizmi Ziyaretçilerinin Müze Memnuniyetlerine İlişkin Değerlendirme, (Editör) Bilim Y. ve Özer, Ö.: İnanç Turizmi Seçme Konular içinde (ss.133156), Konya: Çizgi Kitabevi.

Özer, Ö., Sop, S. A. and Avcı, U. (2013). A Comparison of Museum Visitors' Expectations within the Context of Faith Tourism, International Conference on Religious Tourism and Tolerance, 09-12 May 2013, Konya, p: 57-65.

Pine, B.J.II and Gilmore, J.H. (1998). Welcome to the Experience Economy, Harvard Business Review, 76(4): 97-105.

Prentice, R. (1996). Managing Implosion: The Facilitation of Insight through the Provision of Context, Museum Management and Curatorship, 15(2): 169-185.

Radder, L. and Han, X. (2015). An Examination of the Museum Experience Based on Pine and Gilmore's Experience Economy Realms, Journal of Applied Business Research, 31(2): 455-470.

Sevin, V. (2013). Anadolu'nun Tarihi Coğrafyası, Ankara: Türk Tarih Kurumu.

Sheng, C. W., Shen, M. J. and Chen, M. C. (2008). Special Interest Tour Preferences and Voluntary Simplicity Lifestyle, International Journal of Culture, Tourism and Hospitality Research, 2(4): 389-409.

Sheng, W. C. and Chen, M. C. (2012). A Study of Experience Expectations of Museum Visitors, Tourism Management, 33, 53-60.

Sop, S. A., Yeşiltaş, M. ve Soslu, S. (2019). Fiziksel Çevrenin Müze Ziyaretçileri Üzerine Etkisi: Burdur Müzesi Örneği, Manas Sosyal Araştırmalar Dergisi, 8(4): 3889-3910.

Stoleriu, O. M., Brochado, A., Rusu, A. and Lupu, C. (2019). Analyses of Visitors' Experiences in a Natural World Heritage Site Based on TripAdvisor Reviews, Visitor Studies, 22(2): 192-212.

Trinh, T. T. and Ryan, C. (2013). Museums, Exhibits and Visitor Satisfaction: A Study of the Cham Museum, Danang, Vietnam, Journal of Tourism and Cultural Change, 11(4): 239-263.

Türkiye Kültür Portalı. (2020). https://www.kulturportali.gov.tr/turkiye/burdur/gezilecekyer/burdurmuzesi (Erişim Tarihi: 01.03.2020) 
Yılmaz, O. (2005). Burdur İlinin Turizm Potansiyeli, I. Burdur Sempozyumu, 16-19 Kasım 2005, Burdur, ss. 569-590. 